\title{
RESPONSE OF RHODES GRASS TO VARIABLE RATE APPLICATION OF IRRIGATION WATER AND FERTILIZER NITROGEN
}

\author{
V.C. Patil ${ }^{1,2}$, K.A. Al-Gaadi ${ }^{1,3}$, R. Madugundu ${ }^{1}$, E. Tola ${ }^{1}{ }^{* *}$, S. Marey ${ }^{1}$, D. Mulla ${ }^{4}$ and S. \\ Upadhyaya $^{5}$ \\ ${ }^{1}$ Precision Agriculture Research Chair, King Saud University, Riyadh, Saudi Arabia; ${ }^{2}$ Edith Cowan University, \\ Australia; ${ }^{3}$ Department of Agricultural Engineering, College of Food and Agriculture Sciences, King Saud \\ University, Riyadh, Saudi Arabia; ${ }^{4}$ Department of Soil, Water and Climate, University of Minnesota, St. Paul, \\ Minnesota, USA; ${ }^{5}$ Department of Biological and Agricultural Engineering, University of California, Davis, \\ California, USA. \\ ${ }^{*}$ Corresponding author's e-mail: etola@ksu.edu.sa
}

\begin{abstract}
A field experiment was conducted to study the effects of variable rate application (VRA) of irrigation water and fertilizer nitrogen on the yield of Rhodes grass (Chloris gayana Kunth) under two different management zones (MZ). On a 50 ha field irrigated by center pivot, spilt-split plot design was employed with the $\mathrm{MZ}$ as two main treatments, the four irrigation levels (I1- 100\%, I2- 80\%, I3- 60\% and I4- 40\% of crop evapotranspiration [ET $\mathrm{ET}_{\mathrm{c}}$ ) as sub-treatments and five fertilizer nitrogen levels (F1-240, F2-480, F3-720, F4-960 and F5-1200 $\mathrm{kg} \mathrm{ha}^{-1}$ ) as sub-sub treatments. The mean cumulative Rhodes grass hay yield across three harvests (made in July, September and November 2012) was significantly higher in MZ-2 (24.47 tha ${ }^{-1}$ per harvest) than in MZ-1 $\left(21.78 \mathrm{t} \mathrm{ha}^{-1}\right)$. Deficit irrigation was found to be a suitable water saving strategy in both the management zones. Across the two zones, irrigation at $80 \% \mathrm{ET}_{\mathrm{c}}$ resulted in the highest mean hay yields in first and second harvests (7.58 and 8.77 $\mathrm{t} \mathrm{ha}^{-1}$, respectively), while irrigation at $60 \% \mathrm{ET}_{\mathrm{c}}$ resulted in highest hay yield in the third harvest $\left(8.59 \mathrm{t} \mathrm{ha}^{-1}\right)$. By increasing the nitrogen level from 240 to $480 \mathrm{~kg} \mathrm{ha}^{-1}$, the cumulative hay yield of the three harvests was increased from 21.70 to $22.18 \mathrm{t}$ $\mathrm{ha}^{-1}$ (i.e. increase of 2.21\%) in MZ-1 and from 22.75 to $25.38 \mathrm{t} \mathrm{ha}^{-1}$ (i.e. increase of 11.56\%) in MZ-2, indicating the benefit of VRA of fertilizer nitrogen. Rhodes grass showed differential response to various combinations of irrigation and fertilizer nitrogen levels. A combination of I2-F2 resulted in the highest cumulative Rhodes grass hay yield in both MZ-1 (24.70 $\left.\mathrm{t} \mathrm{ha}^{-1}\right)$ and MZ-2 $\left(27.78 \mathrm{t} \mathrm{ha}^{-1}\right)$. Precision fertigation, involving deficit irrigation at 80\% $\mathrm{ET}_{\mathrm{c}}$ and adopting VRA technology for fertilizer application can be beneficial strategy for enhancing water and fertilizer nitrogen use efficiency for optimal Rhodes grass production.
\end{abstract}

Keywords: Management zones, soil quality, precision agriculture, Rhodes grass, variable rate fertigation

\section{INTRODUCTION}

The demand for forage crops has increased in Saudi Arabia with respect to its large number of livestock (camels, sheep, goats, cattle) which was estimated to be about 3.5 million heads during 2010 (Bakhashwain, 2010). Besides alfalfa, Rhodes grass (Chloris gayana Kunth.) has gained importance (Al-Soqeer and Al-Ghumaiz, 2012) and is widely cultivated in Africa, Australia, Japan, and South America and under irrigation in the Middle East for both forage and soil conservation purposes. Rhodes grass is a morphologically variable out-crossing species, which is native to east, central and southern Africa where it occurs in open grasslands. Rhodes grass is considered as one of the important forage crops cultivated under crop rotation system, and it is recognized as a valuable crop for soil conservation because of its rapid establishment ability and spreading habit useful for soil cover and erosion control (Hayes et al., 2010; Yousif and Ibrahim, 2013a).
Rhodes grass was reported to be responsive to $\mathrm{N}$ fertilizer (Farnworth and Ruxton, 1974) and requires heavy nitrogen (N) fertilization in order to produce high forage yields. However, heavy $\mathrm{N}$-fertilization causes accumulation of free nitrate in the forage which is unfavorable for cattle (Guggenheim and Waisel, 1977). Spectacular linear response to nitrogen at rates of $275-400 \mathrm{~kg} \mathrm{ha}^{-1}$ in the presence of adequate phosphorus and potassium, both in yield and in crude protein content was reported; and split applications after each cut or after grazing cycles were found better than one basic application (Skerman and Riveros, 1990). Rhodes grass was reported to respond to $\mathrm{N}$ rates as high as $1200 \mathrm{~kg}$ $\mathrm{ha}^{-1}$ year $^{-1}$ under center pivot irrigation at Marmul in virgin desert soils and provided an annual dry matter yield of $35 \mathrm{t}$ ha $^{-1}$ (Anonymous, 1988). Prakash et al. (1994) observed a curvilinear response to high rates of nitrogen fertilization (840 $\mathrm{kg} \mathrm{ha}^{-1}$ year $^{-1}$ ), which increased Rhodes grass dry matter yields from 13 to $53 \mathrm{t} \mathrm{ha}^{-1}$ year $^{-1}$ with a recommended application of $\mathrm{N}$ at $120 \mathrm{~kg} \mathrm{ha}^{-1}$ per harvest. Vaisman et al. 
(1982) obtained dry matter yield of $12 \mathrm{tha}^{-1}$ by applying 250 $\mathrm{kg} \mathrm{ha}^{-1}$ of nitrogen to Rhodes grass.

Rhodes grass consumes high amounts of water ranging from $35,000-45,000 \mathrm{~m}^{3} \mathrm{ha}^{-1}$ year $^{-1}$ (Al-Doss, 1997), and dry matter production of 24 to $26 \mathrm{t} \mathrm{ha}^{-1}$ was reported from the irrigated fields in the Mediterranean-type climate of south-west Australia (Roberts and Carbon, 1969). In addition, Vaisman et al. (1982) obtained dry matter yield of $12 \mathrm{tha}^{-1}$ by applying deficit irrigation based on a 0.8 pan evaporation factor.

In Saudi Arabia and other Gulf countries, Rhodes grass is cultivated extensively due to its high productivity and good drought and salt tolerance features that make it a good choice for dry climate locations (Ceccoli et al., 2011; Ibrahim, 1998; Guggenheim et al., 1997; Prakash et al., 1994). The crop is grown under center pivot sprinkler irrigation system. Water consumption for Rhodes grass was in the range of 17,000 to $24,000 \mathrm{~m}^{3} \mathrm{ha}^{-1}$ year $^{-1}$ in Al-Qassim area of Saudi Arabia depending on irrigation system used, climatic conditions and location (Assaeed et al., 2012). However, there are no reports of the effects of variable rate application of irrigation and fertilizer nitrogen levels on the productivity of Rhodes grass from Saudi Arabia. Therefore, the present research work was carried out with the objectives to delineate the field into management zones, and study the effect of Variable Rate Application (VRA) of irrigation water and fertilizer nitrogen on the hay yield of Rhodes grass.

\section{MATERIALS AND METHODS}

The experiment was conducted on a 50 ha field (Pivot TE-11), irrigated using center pivot system, in a commercial farm (Todhia Arable Farm-TAF) located between Al-Kharj and Haradh regions of Saudi Arabia within the latitudes of $24^{\circ} 10^{\prime}$ $22.77^{\prime \prime}$ and $24^{\circ} 12^{\prime} 37.25^{\prime \prime} \mathrm{N}$ and the longitudes of $47^{\circ} 56^{\prime} 14.60^{\prime \prime}$ and $48^{\circ} 05^{\prime} 08.56^{\prime \prime} \mathrm{E}$.

Delineation of management zones (MZ): A management zone is a sub-region of the field which is relatively homogenous (Mulla, 1991, 1993). Management Zone Analyst (MZA) software (Fridgen et al., 2004) was used to delineate MZ of the study field. Fuzzy c-means clustering analysis was adopted inputting composite Normalized Difference Vegetation Index (CNDVI), soil EC and elevation (ASTER DEM) datasets (Patil et al., 2014). A total of eight cloud-free Landsat ETM+ satellite images (November 7 and December 25, 2009; February 11, October 18, November 3 and December 12, 2010; October 21 and December 8, 2011) were downloaded to generate NDVI of each image following Rouse et al. (1973) and a composite stack was prepared to obtain CNDVI. The soil EC layer was created using calibrated geo-referenced EM-38 data. Subsequently, EC data was exported to ArcGIS software and subjected to interpolation (ordinary kriging) to obtain the soil EC layer. The output of MZA file was imported into the mapping program (i.e. ARCGIS) to create the MZ map of the field. The experimental field was delineated in to two management zones based on MZA graphical representation of Fuzziness Performance Index (FPI) and Normalized Classification Entrophy (NCE) performance indices as described by Fraisse et al. (2001) and Lark and Stafford (1997). The MZ map of the experimental field is depicted in Figure 1.

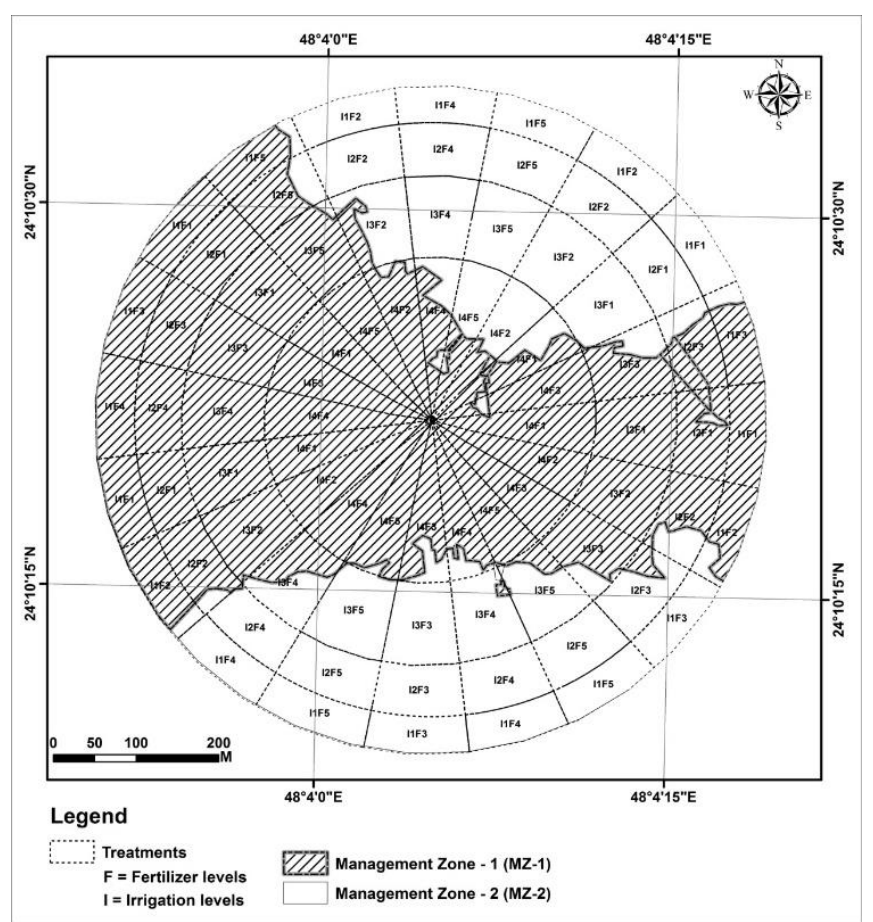

Figure 1. Management zones and layout of experimental treatments (Irrigation and Fertilizer levels) for studying the response of Rhodes grass (Source: Patil et al., 2014).

Experimental details: The experiment was laid out on sandy loam soil with a $\mathrm{pH}$ of 7.58 . The soil contained $72.5 \pm 8.41 \mathrm{mg}$ $\mathrm{kg}^{-1}$ nitrogen (N), $5.35 \pm 3.58 \mathrm{mg} \mathrm{kg}^{-1}$ Phosphorus (P) and $60.8 \pm 28.3 \mathrm{mg} \mathrm{kg}^{-1}$ Potassium (K). The ground water used for irrigation had EC, $\mathrm{pH}$ and Sodium Absorption Ratio (SAR) of $3.18 \mathrm{dSm}^{-1}, 7.21$ and 1.29, respectively. The field experiment was carried out from June to November 2012, on a field irrigated by a center pivot system. The experimental field was delineated into two management zones (MZ) based on soil EC, CNDVI and elevation layers of the experimental field. Descriptive statistics for the parameters used for the delineation of $\mathrm{MZ}$ is provided in Table 1.

Spilt-split plot design was employed with $\mathrm{MZ}$ as two main treatments. Sub-treatments were: irrigation at I1-100, I2-80, I360 and $\mathrm{I} 4-40 \%$ of crop evapotranspiration $\left(\mathrm{ET}_{\mathrm{c}}\right)$; and sub-sub treatments were nitrogen levels: F1-240, F2-480, F3-720, F4960 and $\mathrm{F} 5-1200 \mathrm{~kg} \mathrm{ha}^{-1}$ of fertilizer nitrogen. Irrigation treatments were worked out based on crop water requirement for various crop growth stages and the daily mean ET values recorded on the farm for the period between 1995 and 2012. 
Table 1. Parameters used for the delineation of management zones (MZ) of the experimental field.

\begin{tabular}{l|ccccc|ccccc}
\hline \multirow{2}{*}{ Parameter } & \multicolumn{5}{|c|}{ Management Zone-1 } & \multicolumn{5}{c}{ Management Zone-2 } \\
\cline { 2 - 11 } & Min. & Max. & Mean & SD & SE & Min. & Max. & Mean & SD & SE \\
\hline CNDVI & 0.01 & 0.25 & 0.19 & 0.08 & 0.01 & 0.25 & 0.42 & 0.35 & 0.11 & 0.02 \\
Soil EC $\left(\mathrm{dS} \mathrm{m} \mathrm{m}^{-1}\right)$ & 2.10 & 3.91 & 3.42 & 0.34 & 0.06 & 0.72 & 2.10 & 1.74 & 0.24 & 0.04 \\
Elevation $(\mathrm{m})$ & 363 & 374 & 372 & 3.52 & 0.64 & 363 & 371 & 369 & 3.51 & 0.64 \\
\hline
\end{tabular}

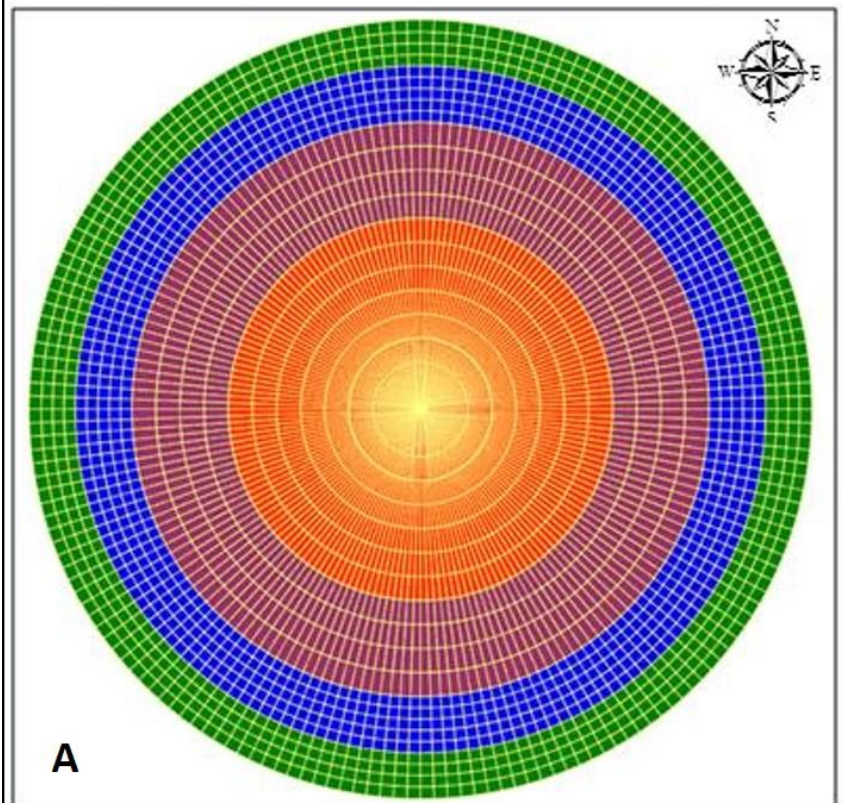

\section{Irrigation levels}

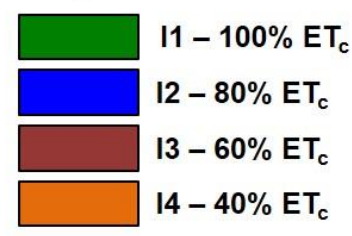

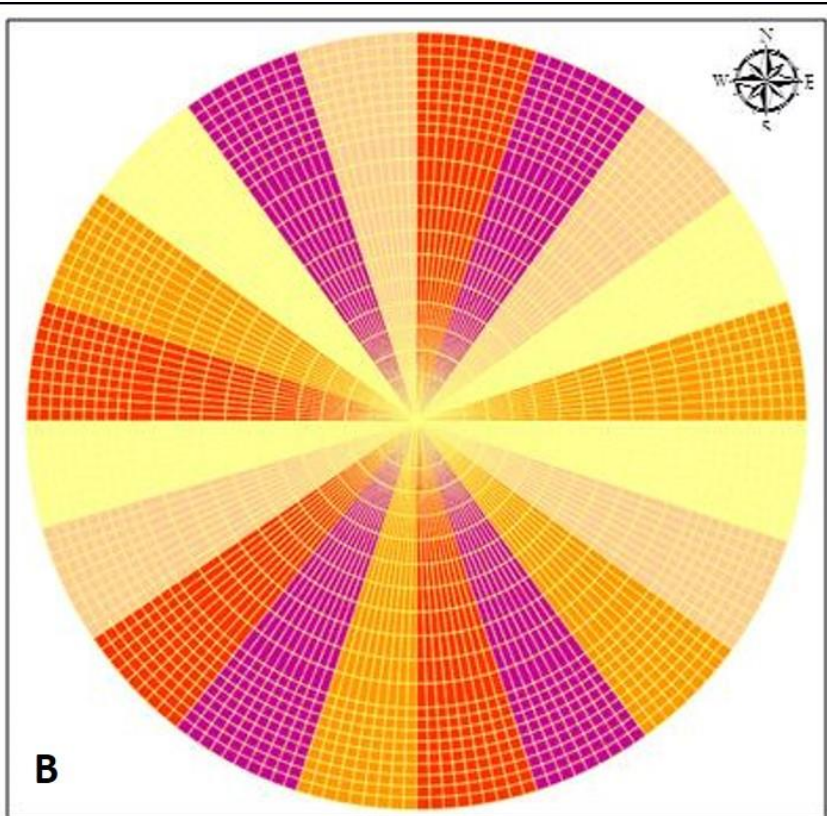

Fertilizer levels

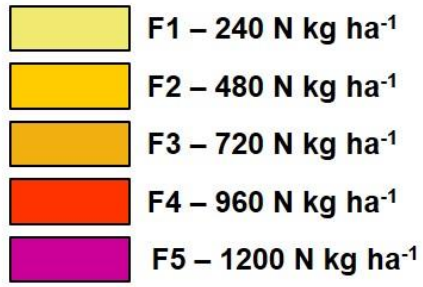

Figure 2. Prescription maps for variable rate application (VRA) of irrigation levels (A) and fertilizer nitrogen levels (B).

While fertilizer nitrogen treatments were applied by splitting the total nitrogen in each treatment based on the crop growth stage. Irrigation and fertilizer nitrogen treatments were applied separately using a Variable Rate Irrigation (VRI) system from Valley Irrigation, USA. Prescription maps used for the execution of both irrigation and fertilizer nitrogen treatments through the VRI system are given in Figure 2.

Determination of Rhodes grass hay yield: The hay yield monitor (Model 880) of Harvest Tec, USA was installed on a large square baler (Claas 3200) to record the harvested biomass yields. Rhodes grass yield of three harvests made in July, September and November 2012 was recorded at the time of baling with a constant baler-chamber pressure of 55 to 60 bars and a vehicle speed of about $10-15 \mathrm{~km} \mathrm{~h}^{-1}$. Moisture content for 100 bales, that were weighed, was measured using a moisture probe (Delmhorst F-2000, Digital Hay Moisture Meter with 18 Inch Probe). The moisture content of the bales varied from 9.8 to $12.2 \%$, and the majority of the bales showed moisture content of about $10.5 \%$. Hence the weight of 100 bales was normalized to $10.5 \%$ moisture content.

Rhodes grass hay yield mapping: Rhodes grass yield data collected using the hay yield monitor was filtered using automated low pass filter of Erdas Imagine (Ver. 2010). The yield maps of three harvests (July, September, and November 2013) illustrated in Figure 3 were prepared by interpolating the filtered point data to a 4 by $4 \mathrm{~m}$ grid using the ordinary 


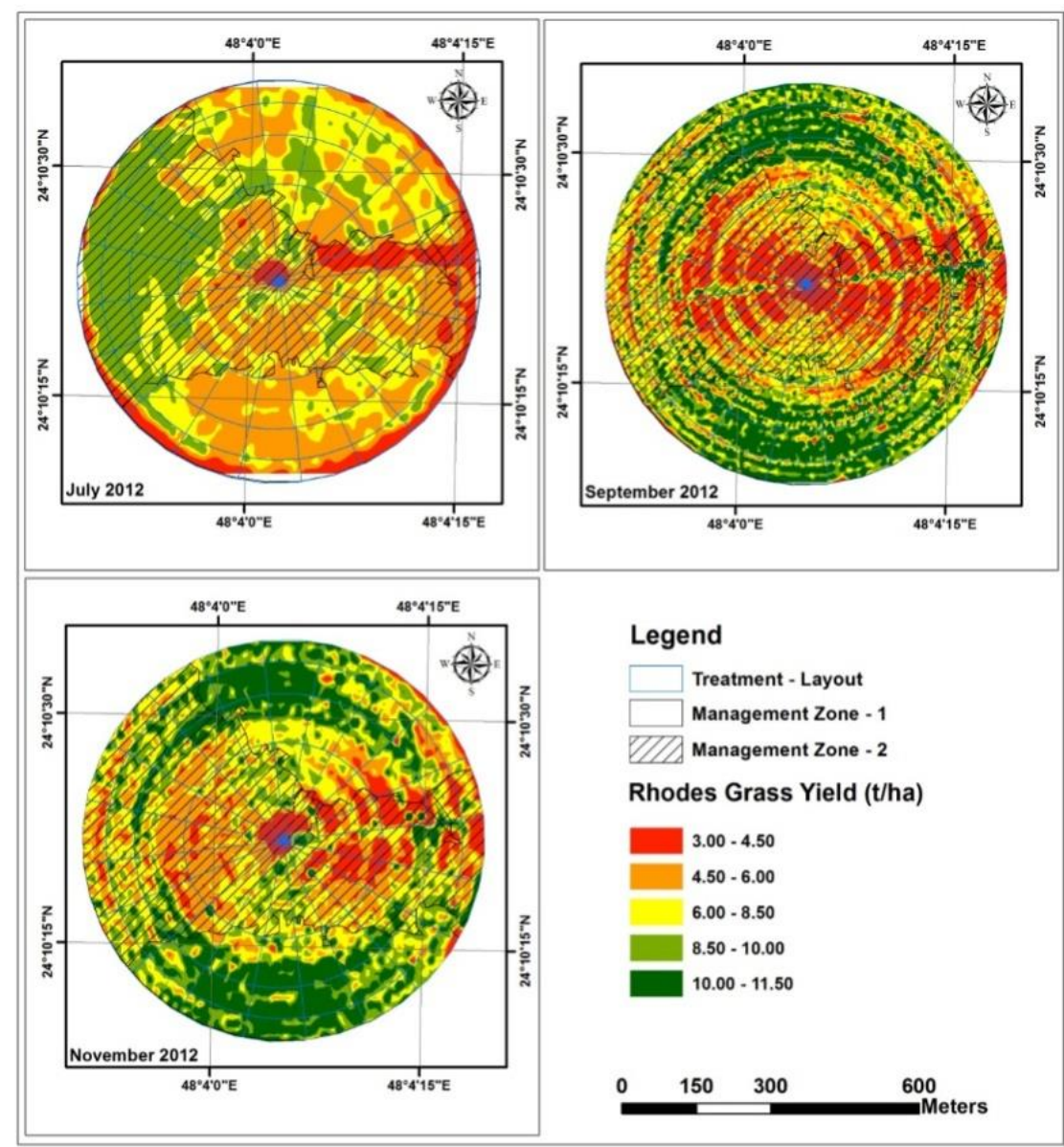

Figure 3. Rhodes grass yield maps developed from yield monitor data of three harvests made in July, September and November 2012.

kriging (Dobermann et al., 2003) tool of ESRI GIS (Ver. 2010). Subsequently, the cumulative yield map (Figure 4) was generated by integrating yield maps of the three harvests.

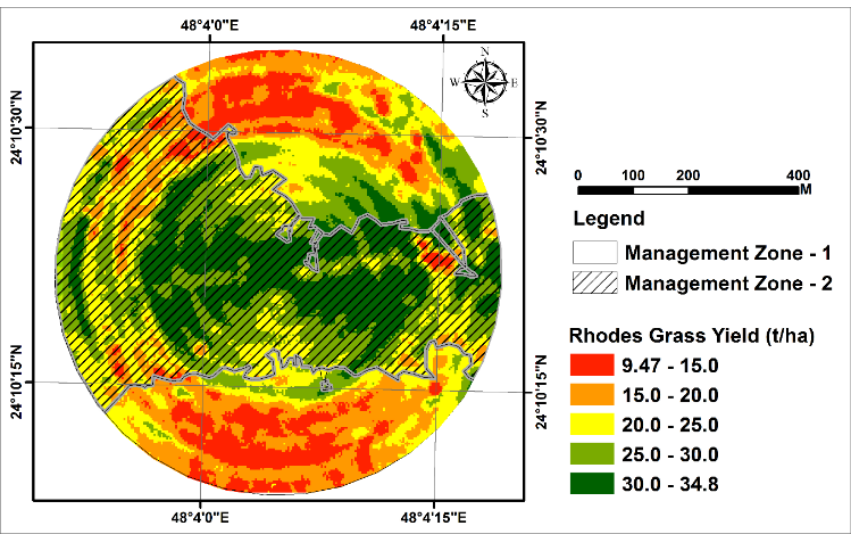

Figure 4. Cumulative Rhodes grass yield map for the three harvests made in July, September and November 2012.
During the preparation of yield maps, low or high yielding strips and points associated with significant turning and maneuvering of the baler were removed (Griffin, 2010). Short segments which were affected by start or end-pass delays were also removed as described by Simbahan et al. (2004).

\section{RESULTS}

Response of Rhodes grass to management zones and precision fertigation: Rhodes grass hay yield monitor data were statistically analyzed and the mean values, for each of the three harvests (July, September and November 2012) are presented in Table 2. While the cumulative yield of the three harvests is given in Table 3. The response of Rhodes grass to management zones, irrigation levels and fertilizer levels was studied and the results are summarized below.

Performance of Rhodes grass in the two management zones: From the yield maps of the three harvests (July, September and November harvests), Figure 3, and the cumulative yield map of the three Rhodes grass harvests (Fig. 4), it can be 
Table 2. Effect of variable rate application (VRA) of irrigation water and fertilizer nitrogen on Rhodes grass yield $\left(\mathrm{t} \mathrm{ha} \mathrm{a}^{-1}\right)$ in two management zones for three harvests.

\begin{tabular}{|c|c|c|c|c|c|c|c|c|c|c|c|}
\hline \multirow[t]{2}{*}{ Fertilizer level } & \multicolumn{5}{|c|}{$\begin{array}{l}\text { Management Zone-1 } \\
\text { Irrigation levels }\end{array}$} & \multicolumn{5}{|c|}{$\begin{array}{l}\text { Management Zone-2 } \\
\text { Irrigation levels }\end{array}$} & \multirow{2}{*}{$\begin{array}{c}\text { Overall } \\
\text { Mean }\end{array}$} \\
\hline & $\mathrm{I}-1$ & $\mathrm{I}-2$ & $\mathrm{I}-3$ & $\mathrm{I}-4$ & Mean & $\mathrm{I}-1$ & $\mathrm{I}-2$ & $\mathrm{I}-3$ & $\mathrm{I}-4$ & Mean & \\
\hline \multicolumn{12}{|c|}{ Harvest - I (July 2012) } \\
\hline F1 & 7.41 & 7.60 & 7.63 & 7.49 & 7.53 & 7.44 & 7.49 & 7.56 & 7.43 & 7.48 & 7.51 \\
\hline $\mathrm{F} 2$ & 7.27 & 7.52 & 7.57 & 7.49 & 7.46 & 7.34 & 7.60 & 7.57 & 7.58 & 7.52 & 7.49 \\
\hline F3 & 7.44 & 7.57 & 7.48 & 7.47 & 7.49 & 7.42 & 7.52 & 7.52 & 7.55 & 7.50 & 7.50 \\
\hline $\mathrm{F} 4$ & 7.67 & 7.73 & 7.59 & 7.54 & 7.63 & 7.34 & 7.56 & 7.56 & 7.58 & 7.51 & 7.57 \\
\hline F5 & 7.58 & 7.63 & 7.57 & 7.52 & 7.57 & 7.34 & 7.55 & 7.55 & 7.60 & 7.51 & 7.54 \\
\hline Mean & 7.47 & 7.61 & 7.57 & 7.50 & & 7.38 & 7.54 & 7.55 & 7.55 & 7.51 & \\
\hline Overall Mean & & & 7.54 & & & & & 7.52 & & & \\
\hline \multicolumn{12}{|c|}{$\begin{array}{c}\text { LSD } 0.05: \text { Management Zones }(M Z)=N S ; \text { Irrigation Levels }(I)=0.058 ; \text { Fertilizer Levels }(F)=N S \\
\text { Harvest - II (September 2012) }\end{array}$} \\
\hline $\mathrm{F} 1$ & 6.38 & 7.63 & 6.29 & 5.48 & 6.44 & 6.99 & 7.68 & 7.37 & 6.14 & 7.04 & 6.74 \\
\hline $\mathrm{F} 2$ & 7.48 & 8.39 & 6.59 & 5.31 & 6.94 & 8.56 & 9.68 & 8.64 & 7.47 & 8.59 & 7.76 \\
\hline F3 & 6.67 & 7.19 & 6.31 & 5.19 & 6.34 & 8.77 & 9.72 & 8.52 & 6.34 & 8.34 & 7.34 \\
\hline F4 & 5.59 & 7.38 & 6.57 & 5.84 & 6.34 & 9.46 & 10.4 & 8.82 & 7.90 & 9.13 & 7.74 \\
\hline F5 & 7.54 & 9.66 & 7.93 & 6.17 & 7.82 & 8.86 & 10.0 & 8.67 & 7.47 & 8.75 & 8.29 \\
\hline Mean & 6.73 & 8.05 & 6.74 & 5.60 & & 8.53 & 9.49 & 8.40 & 7.06 & & 7.57 \\
\hline Overall Mean & & & 6.78 & & & & & 8.37 & & & \\
\hline \multicolumn{12}{|c|}{$\begin{aligned} L S D_{0.05:}: \text { Management Zones }(M Z) & =0.493 ; \text { Irrigation Levels }(I)=0.392 ; \text { Fertilizer Levels }(F)=0.432 \\
& \text { Harvest }- \text { III }(\text { November 2012) }\end{aligned}$} \\
\hline $\mathrm{F} 1$ & 6.72 & 7.34 & 8.60 & 8.27 & 7.73 & 7.52 & 9.11 & 8.26 & 8.04 & 8.23 & 7.98 \\
\hline $\mathrm{F} 2$ & 7.99 & 8.79 & 7.96 & 6.38 & 7.78 & 9.10 & 10.5 & 10.29 & 7.23 & 9.27 & 8.52 \\
\hline F3 & 7.94 & 8.77 & 6.67 & 4.97 & 7.08 & 9.74 & 8.93 & 7.98 & 7.31 & 8.49 & 7.79 \\
\hline $\mathrm{F} 4$ & 6.71 & 5.95 & 7.72 & 6.96 & 6.83 & 9.32 & 6.42 & 8.67 & 7.58 & 8.00 & 7.42 \\
\hline F5 & 8.43 & 7.29 & 9.07 & 6.81 & 7.90 & 9.04 & 8.51 & 10.69 & 7.72 & 8.99 & 8.44 \\
\hline Mean & 7.56 & 7.63 & 8.00 & 6.68 & & 8.94 & 8.69 & 9.18 & 7.58 & & 8.03 \\
\hline Overall Mean & & & & & & & & & & & \\
\hline \multicolumn{12}{|c|}{ LSD $0.05:$ Management Zones $(M Z)=1.801 ;$ Irrigation Levels $(I)=0.497 ;$ Fertilizer Levels $(F)=0.487$} \\
\hline
\end{tabular}

Table 3. Effect of variable rate application (VRA) of irrigation water and fertilizer nitrogen on Rhodes grass cumulative yield $\left(\mathrm{t} \mathrm{ha}^{-1}\right)$ for three harvests.

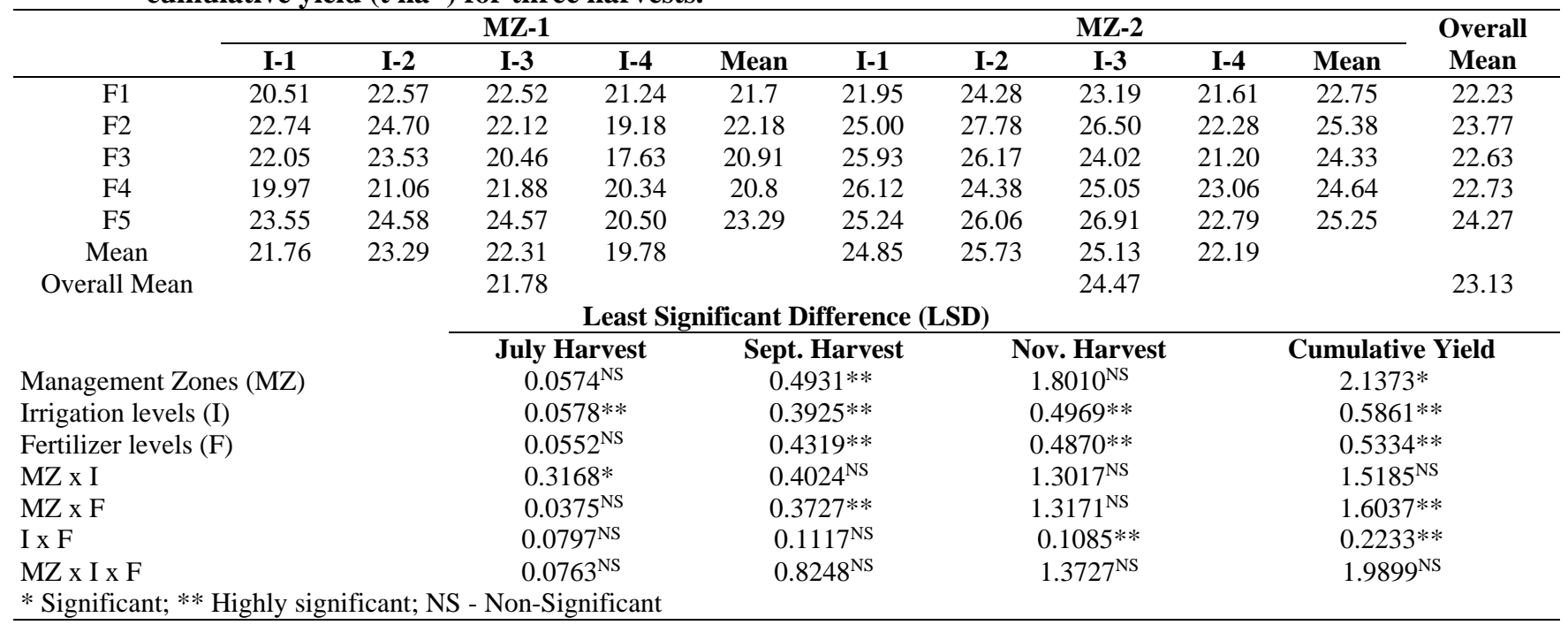

clearly observed that the performance of Rhodes grass under all fertigation treatments was better in management zone 2 (MZ-2) with an overall mean of the cumulative hay yield of
$24.47 \mathrm{t} \mathrm{ha}^{-1}$ compared to $21.78 \mathrm{tha}^{-1}$ in management zone 1 (MZ-1), Table 3. Although the ANOVA results showed significant increase in the cumulative Rhodes grass yield in 
MZ-2 compared to MZ-1, the differences in yield were not statistically significant for July harvest $\left(7.54\right.$ and $7.52 \mathrm{t} \mathrm{ha}^{-1}$ for MZ-1 and MZ-2, respectively) and November harvest (7.47 and $8.60 \mathrm{t} \mathrm{ha}^{-1}$ for MZ-1 and MZ-2, respectively), Table 2. But in September harvest, MZ-2 recorded significantly higher hay yield $\left(8.37 \mathrm{t} \mathrm{ha}^{-1}\right)$ than MZ-1 $\left(6.78 \mathrm{t} \mathrm{ha}^{-1}\right)$.

Response of Rhodes grass to irrigation levels: As depicted in Figure 5, the patterns of the response of the cumulative hay yields to the applied irrigation treatments are same in both management zones. Among the three deficit-irrigation treatments (i.e. irrigation at 80, 60 and $40 \% \mathrm{ET}_{\mathrm{c}}$ ), irrigation at $80 \% \mathrm{ET}_{\mathrm{c}}$ (i.e. I-2) recorded significantly higher mean cumulative yields (23.29 and 25.29 $\mathrm{tha}^{-1}$ in MZ-1 and MZ-2, respectively) than irrigation at $100 \% \mathrm{ET}_{\mathrm{c}}$, i.e. I1 (21.76 and $24.85 \mathrm{t} \mathrm{ha}^{-1}$ in MZ-1 and MZ-2, respectively), Table 3. The results of the cumulative Rhodes grass yield of the three harvests indicated that irrigation at $80 \% \mathrm{ET}_{\mathrm{c}}$ provide better yields (23.93 and $26.93 \mathrm{t} \mathrm{ha}^{-1}$ for MZ-1 and MZ-2, respectively) than the other irrigation levels.

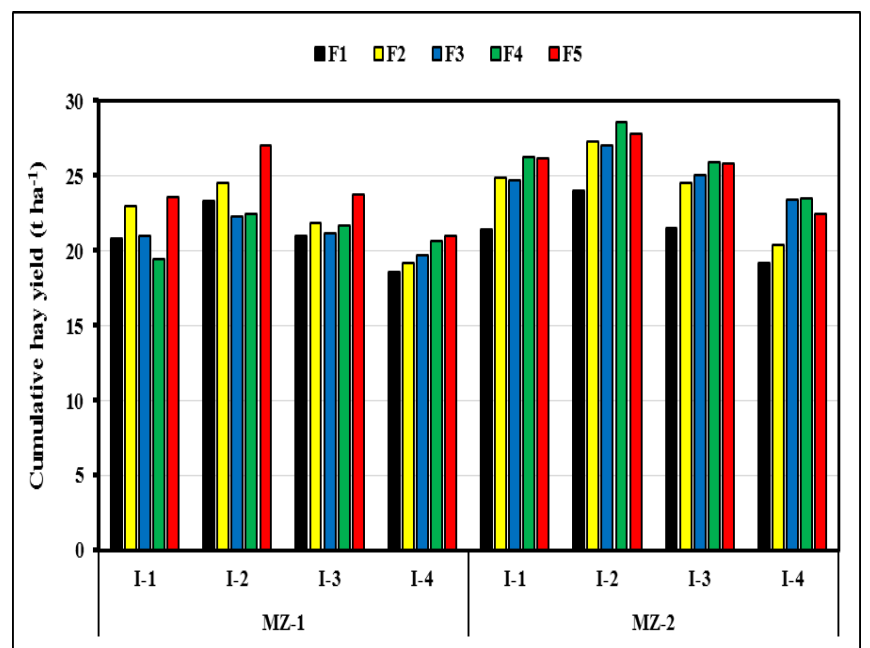

Figure 5. Response of Rhodes grass to management zones (MZ), irrigation (I) and fertilizer (F) levels, based on cumulative hay yield.

In July harvest (Table 2), all the three deficit irrigation treatments (irrigation at 80, 60 and $40 \% \mathrm{ET}_{\mathrm{c}}$ ) recorded significantly higher yields than irrigation at $100 \% \mathrm{ET}_{\mathrm{c}}$ in MZ2. But in MZ-1, irrigation at 80 and $60 \% \mathrm{ET}_{\mathrm{c}}$ were superior to $100 \% \mathrm{ET}_{\mathrm{c}}$. In September harvest, irrigation at $80 \% \mathrm{ET}_{\mathrm{c}}$ recorded significantly higher yield than the other three irrigation levels across both management zones.

For November harvest, irrigation at $40 \% \mathrm{ET}_{\mathrm{c}}$ resulted in significantly lower yield than the other irrigation levels; while the hay yields of the other three irrigation levels were at par. Across the two management zones, irrigation at $80 \% \mathrm{ET}_{\mathrm{c}}$ for the first two harvests and at $60 \% \mathrm{ET}_{\mathrm{c}}$ for the third harvest were beneficial in terms of Rhodes grass production as they resulted in the higher hay yield compared to the other irrigation levels for the same harvests. This implies that, deficit irrigation for Rhodes grass production of up to $80 \%$ $\mathrm{ET}_{\mathrm{c}}$ is possible for the first two harvests. While for the third harvest, deficit irrigation of up to $60 \% \mathrm{ET}_{\mathrm{c}}$ is also possible.

Response of Rhodes grass to fertilizer levels: Variable rate application of fertilizer nitrogen was beneficial in both the harvests made in September and November, 2012. As example, across the management zones and irrigation levels, an increase in the nitrogen level from F1 $\left(240 \mathrm{~kg} \mathrm{ha}^{-1}\right)$ to F2 $\left(480 \mathrm{~kg} \mathrm{ha}^{-1}\right)$ significantly increased Rhodes grass yield from 6.74 to $7.76 \mathrm{t} \mathrm{ha}^{-1}$ (i.e. $15.13 \%$ increase) in September harvest, and from 7.98 to $8.52 \mathrm{t} \mathrm{ha}^{-1}$ (i.e. 6.77\%) in November harvest. In November harvest, across irrigation levels and management zones, application of fertilizer nitrogen at the rate of $480 \mathrm{~kg} \mathrm{ha}^{-1}$ resulted in the higher Rhodes grass hay yield $\left(8.52 \mathrm{t} \mathrm{ha}^{-1}\right)$ compared to that of other fertilizer levels $\left(7.98,7.79,7.42\right.$ and $8.44 \mathrm{tha}^{-1}$ for fertilizer rates of 240, 720, 960 and $1200 \mathrm{~kg} \mathrm{ha}^{-1}$ ). While for the other harvest made in July, the increase in the levels of nitrogen fertilizer did not result in yield enhancement, as indicated by the amounts of the harvested Rhodes grass of 7.51, 7.49, 7.50, 7.57 and 7.54 for the fertilizer levels F1, F2, F3, F4 and F5, respectively. The results of the cumulative Rhodes grass hay yield revealed that the fertilizer applications at F5 (1200 kg ha-1) for MZ-1 and F2 (480 kg ha') for MZ-2 recorded the higher hay yields of 23.29 and $25.38 \mathrm{t} \mathrm{ha}^{-1}$, respectively, than other fertilizer levels. However, by increasing the nitrogen level from (F1) 240 to (F2) $480 \mathrm{~kg} \mathrm{ha}^{-1}$, the cumulative hay yield slightly increased from 21.70 to $22.18 \mathrm{t} \mathrm{ha}^{-1}$ (i.e. $2.21 \%$ increase) in MZ-1, and a significant increase from 22.75 to $25.38 \mathrm{t} \mathrm{ha}^{-1}$ (i.e. $11.56 \%$ increase) in MZ-2. However, an increase of $\mathrm{N}$ fertilizer applications from the lowest level (F1- $\left.240 \mathrm{~kg} \mathrm{ha}^{-1}\right)$ to the highest level (F5 - $1200 \mathrm{~kg} \mathrm{ha}^{-1}$ ) resulted in a significant Rhodes grass yield increase from 21.70 to $23.29 \mathrm{t} \mathrm{ha}^{-1}$ (= $7.33 \%)$ in MZ-1 and from 22.75 to $25.25 \mathrm{t} \mathrm{ha}^{-1}(=10.99 \%)$ in MZ-2. On the average, nitrogen application at $480 \mathrm{~kg} \mathrm{ha}^{-1}$ for MZ-2 and $1200 \mathrm{~kg} \mathrm{ha}^{-1}$ for MZ-1 proved significantly superior to the other fertilizer levels indicating the benefit of variable rate application of fertilizer nitrogen across the experimental field.

Response of Rhodes grass to precision fertigation: The influence of precision fertigation on Rhodes grass hay yield can be clearly observed in Figure 5 which represents the combined effects of variable rate applications of both fertilizer nitrogen and irrigation water on the cumulative hay yield. It was observed that, the combination of I2-F2 (irrigation at $80 \% \mathrm{ET}_{\mathrm{c}}$ and fertilizer nitrogen rate of $480 \mathrm{~kg}$ $\mathrm{ha}^{-1}$ ) was found to be superior to all the other combinations of irrigation and fertilizer levels for both management zones, Table 3. The treatment combination of $\mathrm{I} 2-\mathrm{F} 2$ produced the highest cumulative yields of 24.70 and $27.78 \mathrm{t} \mathrm{ha}^{-1}$ for MZ-1 and MZ-2, respectively. On the other hand, the average yields of the three harvests (derived from Table 2) indicated that the highest Rhodes grass yield recorded in MZ-1 was for I2-F2 
$\left(8.23 \mathrm{t} \mathrm{ha}^{-1}\right)$ followed by I2-F5 and I3-F5 combinations with approximately similar yields of $8.19 \mathrm{t} \mathrm{ha}^{-1}$. While for MZ-2, the highest average yield $\left(9.26 \mathrm{tha}^{-1}\right)$ was recorded for the treatment combination I2-F2, followed by I3-F5 $\left(8.97 \mathrm{t} \mathrm{ha}^{-1}\right)$ and I3-F2 $\left(8.83 \mathrm{t} \mathrm{ha}^{-1}\right)$. These results indicated that the application of variable rate of irrigation water and fertilizer nitrogen, for Rhodes grass production, was beneficial.

\section{DISCUSSION}

The response of Rhodes grass crop to variable rate irrigation was evaluated for three harvests. It was observed that irrigation water application rate significantly influenced Rhodes grass hay yield production. Similar observations were made in an earlier study (ICARDA, 2007), wherein Rhodes grass was observed to be the most responsive crop to water treatments compared to other four grasses (Cenchrus ciliaris, Panicum turgidum, Coelachyrum piercei and Pennisetum divisum) cultivated in the central region of Saudi Arabia. The results indicated that (over the three harvests), irrigation at $80 \% \mathrm{ET}_{\mathrm{c}}$ showed the higher mean cumulative hay yields compared to the other three irrigation levels, for both management zones (23.29 and $25.73 \mathrm{tha}^{-1}$ for MZ-1 and MZ2 , respectively). A 2-years study conducted in Oman (a neighbor country of similar climatic conditions) by the Soil and Water Research Center (2007) reported similar results that when Rhodes grass was irrigated at $0.8 \mathrm{ET}_{\mathrm{p}}$, the result was better productivity and water use efficiency. The results of the present study indicated that the response of Rhodes grass to fertilizer nitrogen levels was of variable manner from one harvest to another as well as between management zones. As example, for November harvest, application of fertilizer nitrogen at a rate of $480 \mathrm{~kg} \mathrm{ha}^{-1}$ resulted in the higher mean hay yield $\left(8.52 \mathrm{tha}^{-1}\right)$ compared to other fertilizer levels (7.98, $7.79,7.42$ and $8.44 \mathrm{t} \mathrm{ha}^{-1}$ for fertilizer rates of 240, 720, 960 and $1200 \mathrm{~kg} \mathrm{ha}^{-1}$, respectively). While for another harvest made in July, the increase in the levels of fertilizer nitrogen did not result in yield enhancement. Generally, application of fertilizer nitrogen at $480 \mathrm{~kg} \mathrm{ha}^{-1}$ for MZ-2 and $1200 \mathrm{~kg} \mathrm{ha}^{-1}$ for MZ-1 showed the best results compared to other fertilizer levels indicating the benefit of variable rate application of fertilizer nitrogen. In a similar study conducted in Sudan, Yousif and Ibrahim (2013b) reported that the response of Rhodes grass to fertilizers was observed to be significant among plant population and yield parameters, but not for other growth parameters (plant height, number of leaves per plant, leaf area index and leaf to stem ratio). As a tropical grass with the $\mathrm{C} 4$ type of photosynthesis, Rhodes grass efficiently uses solar radiation and the available soil moisture to quickly accumulate relatively high amount of biomass (Valenzuela and Smith, 2002). On the other hand, Rhodes grass is considered among grass species that use water more efficiently under dry to medium compared to wet conditions (Marais et al., 2003). Also it was reported that Rhodes grass responds significantly to nitrogen fertilizer, especially after a basic pre-plant application of phosphorus (Brima, 2007; Tolera et al., 2006). Rhodes grass is fairly resistant to water stress, since its roots can extract water from greater soil depths; and it produces higher shoot biomass than other grasses, irrespective of soil water conditions (Eneji et al., 2008). Also previous results showed that Rhodes grass is less sensitive to water stress as evidenced by yield response of 97\% under adequate irrigation compared to Timothy grass (209\%) and tall fescue (122\%), and that the yield response of Rhodes grass across the applied silicon sources under deficit irrigation was significantly higher (205\%) than under adequate irrigation (59\%) (Eneji et al., 2008). In general, increasing water use efficiency of agricultural crops can be attained through the application of adequate amounts of fertilizers. Hence, the combined effect of the studied irrigation and fertilizer levels resulted in $\mathrm{I} 2\left(80 \% \mathrm{ET}_{\mathrm{c}}\right)$ and $\mathrm{F} 2$ $\left(480 \mathrm{~kg} \mathrm{ha}^{-1}\right)$ as an optimum combination for Rhodes grass production under the climatic conditions of the study area. This implies that savings of $20 \%$ in irrigation water could be attained across management zones.

Conclusions: Based on the results of this study, the specific conclusions are: (i) MZ-2 of the experimental field is more productive than MZ-1, (ii) across management zones, irrigation at $80 \% \mathrm{ET}_{\mathrm{c}}$ during the initial period (June to September) and at $60 \% \mathrm{ET}_{\mathrm{c}}$ later (October to November) will result in saving 20 to $40 \%$ of irrigation water for producing Rhodes grass, (iii) for MZ-2, increasing the nitrogen level from 240 to $480 \mathrm{~kg} \mathrm{ha}^{-1}$ will help in optimizing fertilizer $\mathrm{N}$ use for Rhodes grass production, and (iv) a combination of I2 $\left(80 \% \mathrm{ET}_{\mathrm{c}}\right)$ and $\mathrm{F} 2\left(480 \mathrm{~kg} \mathrm{ha}^{-1}\right)$ was observed to be the appropriate irrigation and fertilizer levels for Rhodes grass production under the conditions of the experimental farm. Deficit irrigation (irrigation at $80 \% \mathrm{ET}_{\mathrm{c}}$ ) was beneficial suggesting $20 \%$ saving in irrigation water. Further, saving in $40 \%$ water is possible since higher hay yield of $8.59 \mathrm{t} \mathrm{ha}^{-1} \mathrm{was}$ obtained by irrigation at $60 \% \mathrm{ET}_{\mathrm{c}}$ in the third harvest across the two management zones. This study has indicated the possible benefits of variable rate application of irrigation water and fertilizer nitrogen, which needs confirmation through further studies.

Acknowledgments: This project was financially supported by King Saud University, Vice Deanship of Research Chairs. The assistance provided by graduate students M.E. Abass, A.M. Zeyada and A.G. Kayad in the conduct of field research was quite valuable. The unstinted cooperation and support extended by Mr. Jack King, Mr. Alan King and their team of Todhia Arable Farm in carrying out the research are gratefully acknowledged. 


\section{REFERENCES}

Al-Doss, A.A. 1997. Forage production in Saudi Arabia between expansion and water use conservation, pp.2-10. Proc. First Saudi Meeting for Agricultural Sciences; 2527 March 1997. King Saud University, Riyadh, Saudi Arabia.

Al-Soqeer, A. and N.S. Al-Ghumaiz. 2012. Studies on forage yield and feeding value for some grass species under different irrigation treatment in Al-Qassim region. J. Agric. Vet. Sci. 5:3-16.

Anonymous. 1988. Report of the Desert Agricultural Project, pp.10-15. Petroleum Development Oman, Sultanate of Oman.

Assaeed, A.M., M.I. El-Bana, A.A. Al-Doss and I.A. AlMohaisen. 2012. Forage yield and survival of native range species under supplementary irrigation in Central Saudi Arabia. Afr. J. Agric. Res. 7:3933-3938.

Bakhashwain, A.A. 2010. Fodder yield and quality of Rhodes grass-Alfalfa mixtures as affected by sowing rates in Makkah region. JKAU: Metorol. Environ. Arid Land Agric. Sci. 21:19-33.

Brima, F.I.A. 2007. Effects of seed rate and NPK fertilization on growth, yield and forage quality of Rhodes grass (Chloris gayana Kunth). M.Sc. Diss., Fac. of Agriculture, Univ. of Khartoum, Khartoum, Sudan.

Ceccoli, G., J.C. Ramos, L.I. Ortega, J.M. Acost and M.G. Perreta. 2011. Salinity induced anatomical and morphological changes in Chloris gayana Kunth roots. Biocell 35:9-17.

Dobermann, A., J.L. Ping, V.I. Adamchuk, G.C. Simbahan and R.B. Ferguson. 2003. Classification of crop yield variability in irrigated production fields. Agron. J. 95:1105-1120.

Eneji, A.E., S. Inanaga, S. Muranaka, J. Li, T. Hattori, P. An and W. Tsuji. 2008. Growth and Nutrient use in four grasses under drought stress as mediated by silicon fertilizers. J. Plant Nutr. 31:355-365.

Farnworth, J. and I.B. Ruxton. 1974. The effect of nitrogen on the productivity and composition of Rhodes grass (Var. Katambora) grown under irrigated arid zone conditions, p.15. Joint Agric. Res. and Development Project Publication No. 37; Univ. Coll. North Wales and Ministry of Agric. and Water, Saudi Arabia.

Fraisse, C.W., K.A. Sudduth and N.R. Kitchen. 2001. Delineation of site-specific management zones by unsupervised classification of topographic attributes and soil electrical conductivity. Trans. ASAE 44:155-166.

Fridgen, J.J., N.R. Kitchen, K.A. Sudduth, S.T. Drummond, W.J. Wiebold and C.W. Fraisse. 2004. SOFTWARE: Management Zone Analyst (MZA): Software for subfield management zone delineation. Agron. J. 96:100-108.

Griffin, T.W. 2010. The spatial analysis of yield data, p.89113. In: M.A. Oliver (ed.), Geostatistical Applications for
Precision Agriculture. Springer Science and Business Media, New York, USA.

Guggenheim, J., Y. Waisel, E. Taleisnik, G. Peyrano and C. Arias. 1997. Response of Chloris gayana cultivars to salinity: 1. Germination and early vegetative growth. Trop. Grasslands 31:232-240.

Guggenheim, J. and Y. Waisel. 1977. Effects of salinity, temperature and nitrogen fertilization on growth and composition of Rhodes grass (Chloris gayana Kunth). Plant Soil 47:431-440.

Hayes, R.C., B.S. Dear, G.D. Li, J.M. Virgona and M.K. Conyers. 2010. Perennial pastures for recharge control in temperate drought-prone environments. Part 1: productivity, persistence and herbage quality of key species. New Zeal. J. Agr. Res. 53:283-302.

Ibrahim, Y.A. 1998. Rhodes grass evaluation- evaluation of Rhodes grass cultivars under Emirates condition. Tropicultura 3:147-149.

ICARDA. 2007. Sustainable management of natural resources and improvement of the major production systems in the Arabian Peninsula. Final report 2000-2005 Arabian Peninsula Regional Program. International Center for Agricultural Research in the Dry Areas (ICARDA), Aleppo, Syria.

Lark, R.M. and J.V. Stafford. 1997. Classification as a first step in the interpretation of temporal and spatial variation of crop yield. Ann. Appl. Biol. 130:111-121.

Marais, D., N. Rethman and J. Annanda. 2003. Dry matter yield and water use efficiency of five perennial subtropical grasses at four levels of water availability. Afr. J. Range Forage Sci. 23:165-169.

Mulla, D.J. 1993. Mapping and managing spatial patterns in soil fertility and crop yield, p. 15-26. In: P. Robert, W. Larson and R. Rust (eds.), Soil Specific Crop Management. Am. Soc. Agronomy, Madison, WI.

Mulla, D.J. 1991. Using geostatistics and GIS to manage spatial patterns in soil fertility, pp. 336-345. In: G. Kranzler (ed.), Automated Agriculture for the $21^{\text {st }}$ Century. Am. Soc. Agric. Eng., St. Joseph, MI., USA.

Patil, V.C., K.A. Al-Gaadi, R. Madugundu, E.H.M. Tola, S.A. Marey, A.M. Al-Omran, R. Khosla, S.K. Upadhyaya, D.J. Mulla and A. Al-Dosari. 2014. Delineation of management zones and response of spring wheat (Triticum aestivum) to irrigation and nutrient levels in Saudi Arabia. Int. J. Agric. Biol. 16:104-110.

Prakash, K.S., A. Mani and T. Al-Zidgali. 1994. Effect of nitrogen, phosphorus and potassium fertilization on herbage yield, quality and plant parasitic nematode populations in an irrigated Rhodes grass (Chloris gayana) pasture in Oman. Trop. Grasslands 28:164-169.

Roberts, F.J. and B.A. Carbon. 1969. Growth of tropical and temperate grasses and legumes under irrigation in SouthWest Australia. Trop. Grasslands 3:109-116. 
Rouse, J.W., R.H. Hass, J.A. Schell and D.W. Deering. 1973. Monitoring vegetation systems in the Great Plains with ERTS, p. 309-317. Third Earth Resources Technology Satellite-1 Symposium, 10-14 December 1973, Washington, USA.

Simbahan, G.C., A. Dobermann and J.L. Ping. 2004. Screening yield monitor data improves grain yield maps. Agron. J. 96:1091-1102.

Skerman, P.J. and F. Riveros. 1990. Tropical grasses. FAO Plant Production and Protection Series No. 23. Food and Agriculture Organization of the United Nations. Rome, Italy.

Soil and Water Research Center. 2007. Effects of irrigation on the yield and water-use efficiency of Rhodes grass (Chloris gayana) in Batinah region, pp.323-329. Agricultural and Livestock Research - Annual Report 2007, Sultanate of Oman.

Tolera, A., A. Kidane and W. Tesfamariam. 2006. The effect of nitrogen fertilization and cutting age on dry matter yield and protein content of Rhodes grass at Awassa, southern Ethiopia. Trop. Sci. 46:87-91.

Vaisman, I., J. Shalhevet, T. Kipnis and A. Feigin. 1982. Water regime and nitrogen fertilization for Rhodes grass irrigated with municipal waste water on sand dune soil. J. Environ. Qual. 11:230-232.

Valenzuela, H. and J. Smith. 2002. Rhodes grass, sustainable Agriculture, cover crops/SA-CC-3. Cooperative Extension Service, Collage of Tropical Agriculture and Human Resources. University of Hawaii. Available online with updates at www.ctahr.hawaii.ed

Yossif, A.A. and Y.M. Ibrahim. 2013a. Effect of organic and inorganic fertilizers on proximate analysis of Rhodes grass (Chloris gayana L. Knuth). Univ. J. Plant Sci. 1:137-140.

Yossif, A.A. and Y.M. Ibrahim. 2013b. Effect of fertilizers (urea, farmyard and chicken manure) on growth and yield of Rhodes grass (Chloris Gayana L. Knuth). Univ. J. Plant Sci. 1:85-90. 